\title{
Extranodal Rosai Dorfman disease mimicking multiple liver metastases
}

\section{Che Liu, Peng Liu}

Department of Hepatobiliary surgery, The Sixth Medical Center of PLA General Hospital, Beijing, China

Correspondence to: Peng Liu, MD. Department of Hepatobiliary Surgery, The Sixth Medical Center of PLA General Hospital, 6 Fucheng Road, Beijing 100048, China. Email: liupeng_pla@163.com.

Submitted Aug 06, 2020. Accepted for publication Sep 07, 2020.

doi: $10.21037 / \mathrm{hbsn}-20-642$

View this article at: http://dx.doi.org/10.21037/hbsn-20-642

A 59-year-old female patient was admitted to our center complaining of upper abdominal pain, fatigue, and intermittent fever for the past 4 months. Her cancer antigen 125 (CA125) level was $143.8 \mathrm{U} / \mathrm{mL}$. The computed tomography (CT) scan showed multiple low-density foci in the liver with arterial enhancement, suggestive of liver metastases (Figure 1A). Meanwhile, the positron emission tomography (PET)/CT scan demonstrated multiple FDG avid lesions in the liver with multiple enlarged lymph nodes in the left supraclavicular, mediastinal, supradiaphragmatic, hilar, and retroperitoneal regions, suggestive of liver and lymph nodal metastases (Figure 1B). The biopsy was
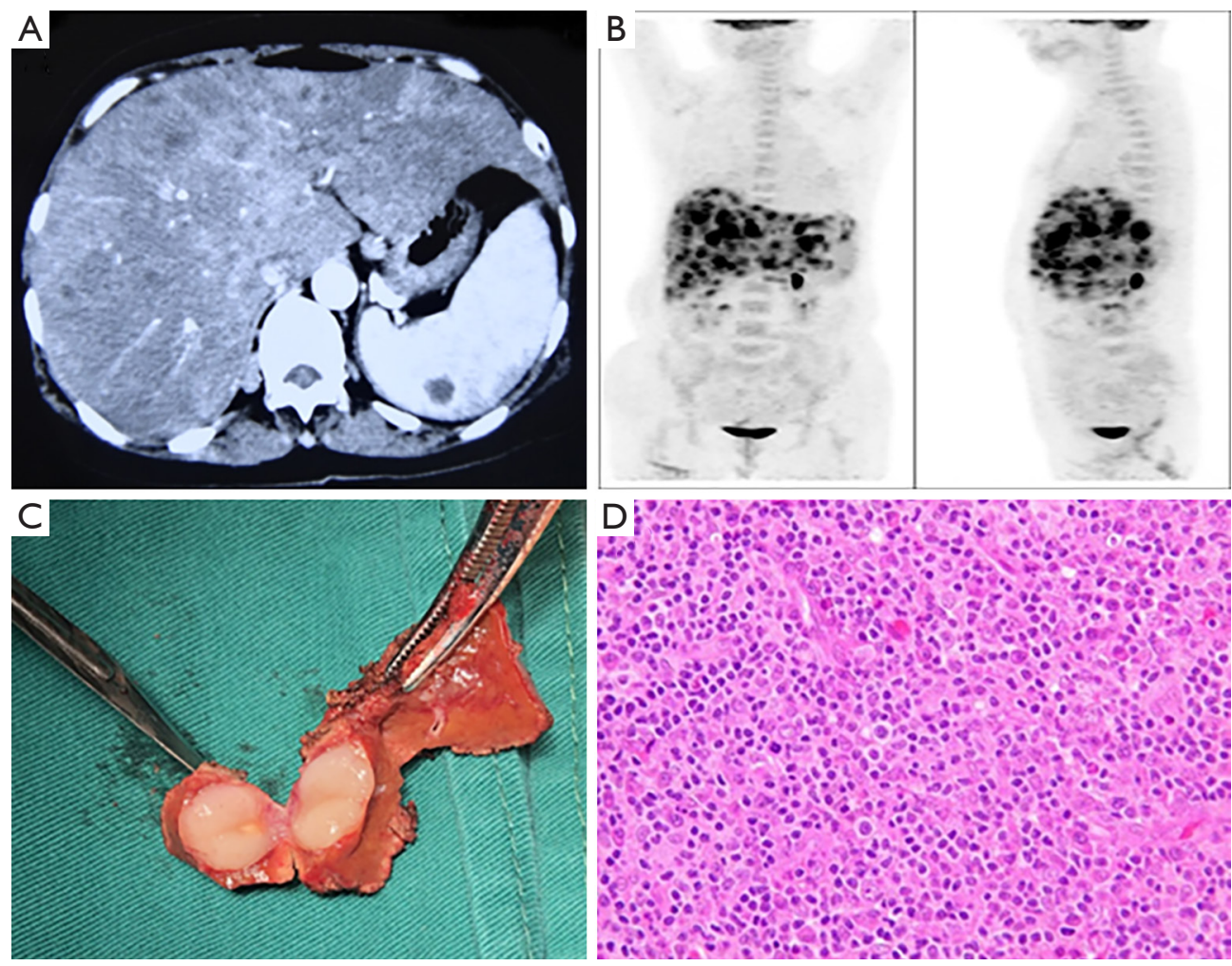

Figure 1 Imaging findings of the patient. (A) CT scan suggesting multiple liver metastases; (B) PET/CT scan suggesting multiple liver metastases; (C) surgical specimen; (D) HE staining of tissue section ( $\times 200)$. PET, positron emission tomography; CT, computed tomography. 
inconclusive. Therefore, a tuberectomy of the left lateral lobe of the liver was performed (Figure 1C). The HE staining showed histiocytic and T-lymphocytic reactive or proliferative lesions (Figure 1D). The final pathological diagnosis was extranodal Rosai Dorfman disease. Afterward, the patient had no complaints, and after 7 months of followup, the liver CT scan revealed complete remission.

\section{Acknowledgments}

The authors thank Professor Wen-Rui Zhao providing help to this research.

Funding: None.

\section{Footnote}

Provenance and Peer Review: This article is a standard submission to the editorial office, Hepatobiliary Surgery and Nutrition. The article did not undergo external peer review.

Conflicts of Interest: Both authors have completed the
ICMJE uniform disclosure form (available at https://hbsn. amegroups.com/article/view/10.21037/hbsn-20-642/coif). The authors have no conflicts of interest to declare.

Ethical Statement: The authors are accountable for all aspects of the work in ensuring that questions related to the accuracy or integrity of any part of the work are appropriately investigated and resolved. Written informed consent was obtained from the patient for publication of this manuscript and any accompanying images.

Open Access Statement: This is an Open Access article distributed in accordance with the Creative Commons Attribution-NonCommercial-NoDerivs 4.0 International License (CC BY-NC-ND 4.0), which permits the noncommercial replication and distribution of the article with the strict proviso that no changes or edits are made and the original work is properly cited (including links to both the formal publication through the relevant DOI and the license). See: https://creativecommons.org/licenses/by-nc-nd/4.0/.
Cite this article as: Liu C, Liu P. Extranodal Rosai Dorfman disease mimicking multiple liver metastases. HepatoBiliary Surg Nutr 2021;10(2):297-298. doi: 10.21037/hbsn-20-642 